\title{
MORPHOMETRIC ASSESSMENT OF CANINE HEART WITHOUT MACROSCOPICALLY VISIBLE CHANGES CAUSED BY CARDIAC DISEASE
}

\section{AVALIAÇÃO MORFOMÉTRICA DO CORAÇÃO CANINO SEM ALTERAÇÕES MACROSCÓPICAS DE DOENÇA CARDÍACA}

\author{
Layla Lívia Queiroz ${ }^{1}$ \\ Léa Resende Moura² \\ Veridiana Maria Brianezi Dignani Moura ${ }^{*}$ \\ ${ }^{1}$ Centro Universitário UniEvangélica, Anápolis, GO, Brazil. \\ 2Universidade Federal de Goiás, Goiânia, GO, Brazil. \\ *Corresponding author - vdmoura@hotmail.com
}

\begin{abstract}
The purpose of this study was to collect data on the cardiac morphometry of thirty adult male and female dogs without macroscopic changes indicative of heart disease, regardless of animal's body weight and score. The dogs were weighed, grouped according to their body weight, and necropsied for a macroscopic evaluation of their cardiac measurements. The data obtained were included in a database. The following cardiac measures were evaluated: vertical and horizontal axes, weight, volume, thickness of the right and left atria and ventricles, and horizontal and vertical axes of the atrial and ventricular chambers. The heart weight was found to represent 0.6 to $1.1 \%$ of the animal's body weight. No differences were found in cardiac size and weight as a function of sex. The ratio between the vertical and horizontal cardiac axes was 1.11. The left ventricle was found to be 1.6 to threefold thicker than the right ventricle. The results were considered standard for dogs and can be used for macroscopic evaluations of cardiac hypertrophy or dilation.
\end{abstract}

Keywords: atria; dog; heart chambers; myocardium; ventricles.

\section{Resumo}

Avaliou-se morfometricamente o coração de 30 cães adultos, sem histórico de doença cardíaca, sem restrição quanto ao porte e escore corporal, encaminhados para exame necroscópico e que não apresentavam alterações macroscópicas. A maioria dos animais era sem raça definida, sendo 14 machos e 16 fêmeas. Observou-se correlação positiva do peso dos cães com o tamanho do coração, com a espessura das paredes dos ventrículos e átrios, assim como com a largura e o comprimento das câmaras. Ainda, não foi constatada correlação entre a espessura dos átrios direito e esquerdo e o peso dos animais. A relação entre o peso cardíaco e o peso corpóreo dos cães foi mensurada individualmente, obtendo-se que o peso do coração representa de $0,6 \%$ a $1,1 \%$ do peso corporal. Não foram observadas diferenças relacionadas ao sexo. Na avaliação do quociente de relação entre os eixos cardíacos vertical e horizontal obteve-se o índice de 1,11 +/- 0,21. Em relação à proporção da espessura muscular dos ventrículos esquerdo e direito, obteve-se espessura do ventrículo esquerdo 1,6 a três vezes maior que a do ventrículo 
direito. Os dados desta pesquisa contribuem na construção de tabelas com valores de referência das diferentes medidas cardíacas em cães.

Palavras-chave: átrios; câmaras cardíacas; cão; miocárdio; ventrículos.

Received on: October 17th, 2016

Accepted on: February 28th, 2018

\section{Introduction}

The distinct layer of cardiac muscle, called the myocardium, consists of muscle cells (cardiomyocytes), which are arranged in overlapping spiral patterns ${ }^{(1)}$. The thickness of the myocardium is determined by the pressure in each chamber. While the atria are thin, the ventricles are thick. The wall of the left ventricle is approximately threefold thicker than that of the right ventricle and can become even thicker to compensate for increased physiological or pathological circulatory overload ${ }^{(2)}$.

Dogs' hearts differ in shape and position from those of other domestic species ${ }^{(3)}$, presenting an ovoid aspect with a blunt and rounded apex ${ }^{(4)}$. The absolute weight of the heart of a medium size dog is 40 to $600 \mathrm{~g}$, corresponding to 0.9 to $2.2 \%$ of its body weight. However, the relative weight varies widely and is greater in hunting dogs and in dogs trained for speed or work. On the other hand, the heart weight of obese and sedentary dogs may represent only about $0.5 \%$ of their body weight ${ }^{(3)}$.

Sex-related morphometric differences in the canine heart are considered negligible ${ }^{(5)}$. On the other hand, heart diseases can manifest as changes in the size and weight of the components of the heart, in degrees proportional to the severity of the disease, as occurs in hypertrophic and dilated cardiomyopathies ${ }^{(6)}$. In the case of physiological or pathological cardiac overload, ventricular hypertrophy is one of the first and main compensatory mechanisms ${ }^{(7)}$. Given such numerous variations, data on canine heart size are scarce, particularly as it pertains to the size of the animals, which often hinders or leads to underestimations in the diagnosis of heart disease manifested by alterations in heart shape and size ${ }^{(6)}$.

The term morphometry is widely applied in science. Ultimately, in biomedicine, it involves the measurement of anatomical structures in order to obtain more objective and accurate data, the presentation and analysis of results obtained in research and laboratory routines, and the identification of relations between the various anatomical structures and functions ${ }^{(8)}$. Most of the cardiac measurements described in the literature refer to data obtained by echocardiography on dogs of specific breeds ${ }^{(9-11)}$. However, references to evaluate cardiomyopathies in mongrel dogs are also important for anatomopathological routine. The purpose of this study was to collect data on the cardiac morphometry of adult dogs that did not present macroscopic changes suggestive of heart disease and also to relate such measurements to the body weight of the animals.

\section{Material and Methods}

This research was conducted at the Department of Animal Pathology of the School of Veterinary Medicine and Animal Science (EVZ) of the Federal University of Goias (UFG) in Goiania, Goias 
state, Brazil. The study involved 30 adult dogs that had been destined for necropsy, comprising 14 males and 16 females, most of them mongrels. The animals were weighted individually on an electronic scale, necropsied and their hearts morphometrically measured.

The pericardial sac of each animal was opened to expose the heart. The vertical and horizontal axes, starting at the midpoint of each axis, were measured with a caliper (FIGURE 1A). A longitudinal midline incision was then made from the apex to the base of the heart to expose the cardiac chambers, especially the ventricles (Figure 1B). The heart was washed to remove blood clots and weighed on electronic scales. Both the thickness of the atrial and ventricular walls and the width and length of the chambers were measured with a caliper, always starting from the midpoint of each axis (Figures 2A, $2 \mathrm{~B}, 2 \mathrm{C}$, and 2D). It should be noted that the cardiac measurements were taken using only hearts that presented no change in volume visible under macroscopic examination.

Cardiac volume was measured based on the volume of water displaced upon placing the heart in a graduated beaker (in $\mathrm{mm}$ ). The data from each animal and the morphometric evaluation of the heart were transcribed onto individual charts and then to a database.

After analyzing the material, the animals were divided into seven groups according to body weight in order to evaluate the minimum and maximum reference values for the cardiac measurements, as well as the average and standard deviation of each measure. The groups comprised weights of 1 to $4 \mathrm{~kg}, 4.1$ to $8 \mathrm{~kg}, 8.1$ to $12 \mathrm{~kg}, 12.1$ to $16 \mathrm{~kg}, 16.1$ to $20 \mathrm{~kg}, 20.1$ to $24 \mathrm{~kg}$, and 28 to $32 \mathrm{~kg}$. There was no dog in the weight range of 24.1 to $28 \mathrm{~kg}$. The mean \pm two standard deviations of each variable were considered for purposes of normality.

The relation between body weight and heart weight, between the size of the heart and the animal's sex, the ratio between the measurements of vertical and horizontal cardiac axes, and between the thickness of the left and right ventricles were evaluated.
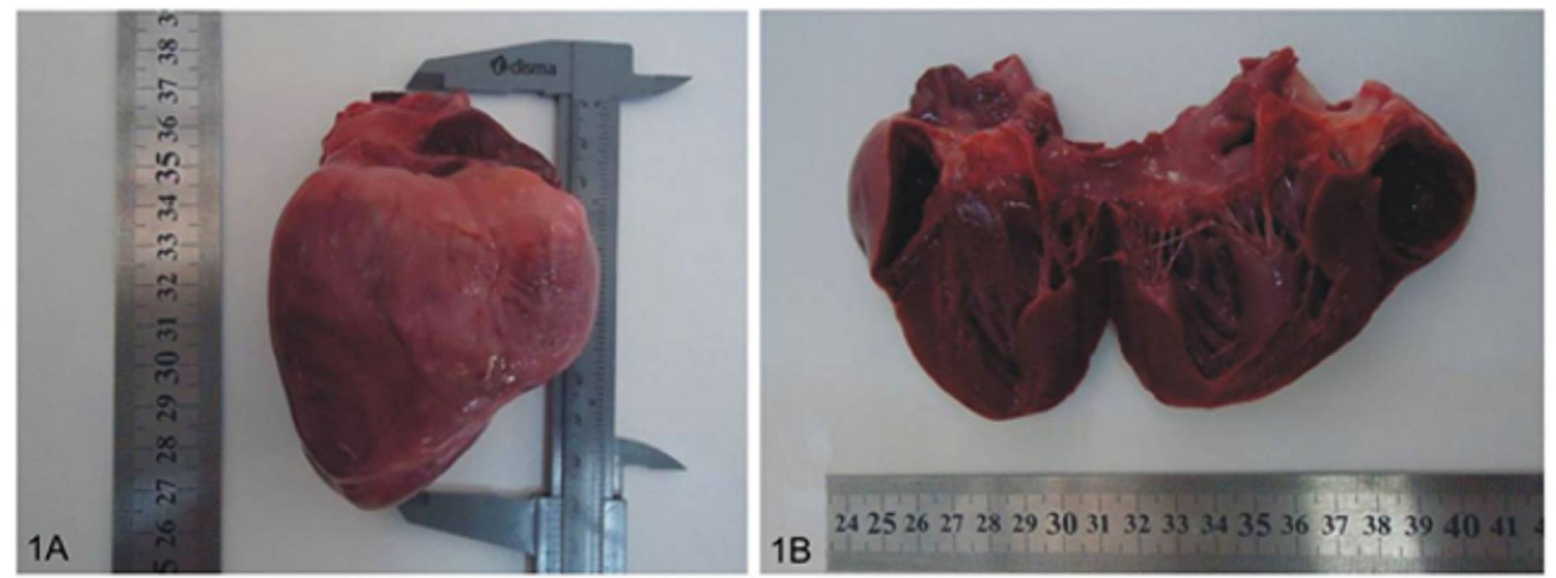

Figure 1. Canine Heart. A) Measurement of the cardiac vertical axis. B) Longitudinal opening and exposure of the cardiac chambers. 

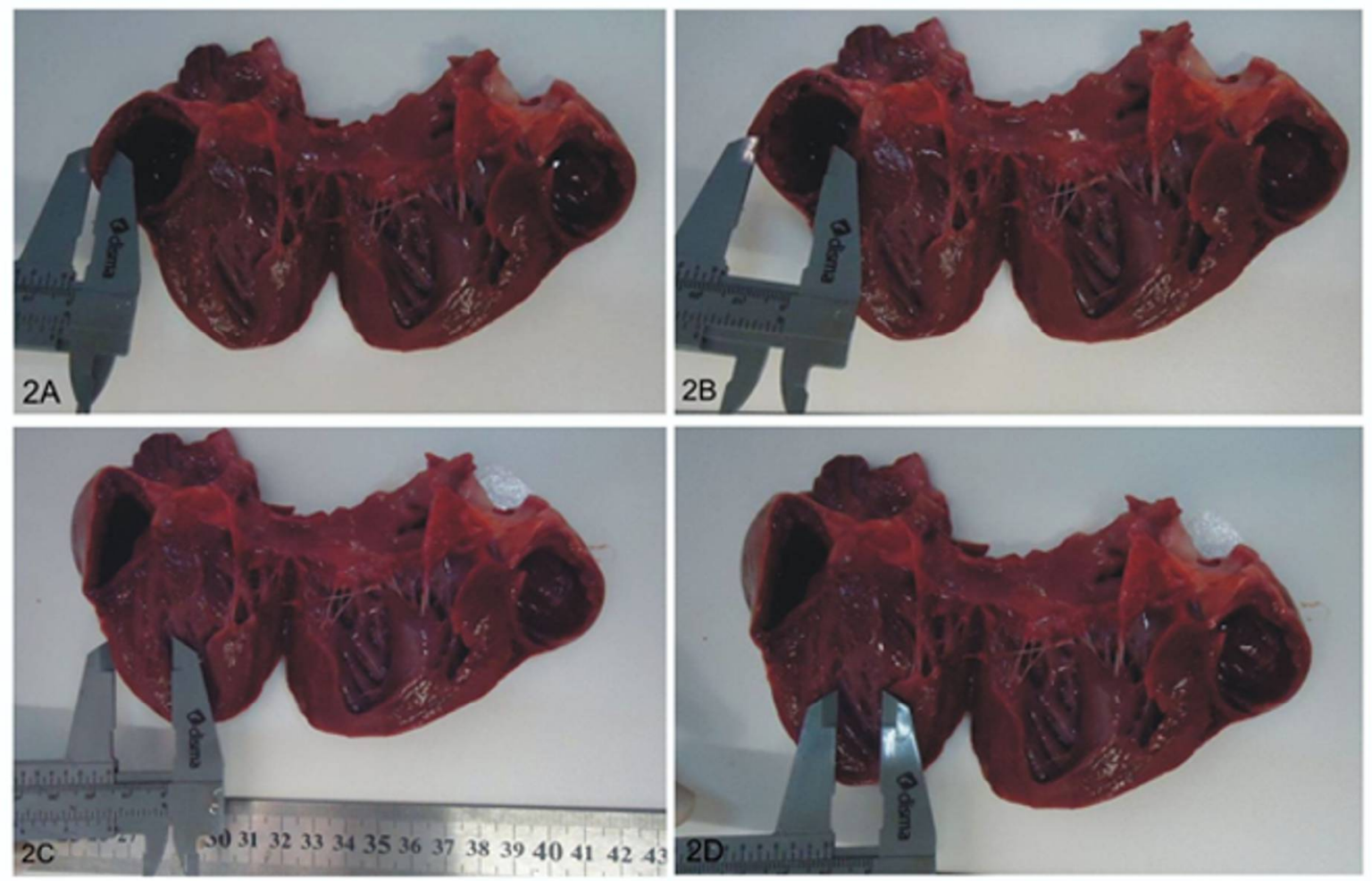

Figure 2. Canine Heart. Measurement of wall thickness and lumens of the cardiac chambers. A) Thickness of the right ventricular wall. B) Width of the right ventricular lumen. C) Thickness of the left ventricular wall. D) Width of the left ventricular lumen.

\section{Results}

The two weight groups between 4.1 and $12 \mathrm{~kg}$ included $43 \%$ of our sample $(n=13)$. The minimum and maximum values of the internal and external cardiac measurements and the mean and standard deviation are listed in Tables 1 and 2.

A positive correlation was found between the weight of the dogs and all the cardiac measures evaluated, except for the thickness of the right and left atria, which showed either a negative correlation or no correlation with the weight of the animals.

The relation between heart weight and body weight was measured individually (Table 3), revealing that the heart weight represent $0.6 \%$ to $1.1 \%$ of the animal's body weight. No significant differences were observed in heart size and weight or in the relation between heart and body weight as a function of sex.

The relative ratio between the vertical and horizontal cardiac axes was determined, indicating a ratio of $1.11+/-0.21$, which is useful to assess the proportional size of the canine heart, regardless of body weight.

As for the proportion of muscle thickness of the left and right ventricles, the left ventricle was found to be 1.6 to 3 -fold thicker than the right ventricle, as shown in Figure 3. 
Table 1. Measurements, mean (M), and standard deviation (SD) of the canine heart morphometric variables as a function of the animal's weight

\begin{tabular}{llllllllll}
\hline $\begin{array}{l}\text { Weight } \\
\text { range } \\
(\mathrm{kg})\end{array}$ & Variables & $\begin{array}{l}\text { CV axis } \\
(\mathrm{cm})\end{array}$ & $\begin{array}{l}\mathrm{CH} \\
\text { axis } \\
(\mathrm{cm})\end{array}$ & $\begin{array}{l}\text { Heart } \\
\text { weight } \\
(\mathrm{g})\end{array}$ & $\begin{array}{l}\text { Volume } \\
\left(\mathrm{cm}^{3}\right)\end{array}$ & $\begin{array}{l}\text { Thickness } \\
\text { RV }(\mathrm{cm})\end{array}$ & $\begin{array}{l}\text { Thickness } \\
\text { LV }(\mathrm{cm})\end{array}$ & $\begin{array}{l}\text { Thickness } \\
\text { RA }(\mathrm{cm})\end{array}$ & $\begin{array}{l}\text { Thickness } \\
\text { LA }(\mathrm{cm})\end{array}$ \\
\hline & Min-Max & $4.5-5.9$ & $3.5-4.7$ & $24-34$ & $24-40$ & $0.4-0.6$ & $1.0-1.4$ & 0.1 & $0.05-0.2$ \\
$1-4(\mathrm{n}=3)$ & M & 5.1 & 3.97 & 27.67 & 29.67 & 0.47 & 1.13 & 0.1 & 0.12 \\
& SD & 0.72 & 0.64 & 4.87 & 8.96 & 0.12 & 0.23 & 0 & 0.08 \\
$4.1-8$ & Min-Max & $5.8-6.7$ & $4.7-5.9$ & $41-64$ & $35-60$ & $0.4-0.6$ & $1.0-1.5$ & $0.1-0.2$ & $0.1-0.2$ \\
$(\mathrm{n}=7)$ & M & 6.2 & 5.36 & 52.92 & 46.25 & 0.47 & 1.16 & 0.17 & 0.14 \\
& SD & 0.37 & 0.36 & 7.96 & 11.09 & 0.08 & 0.17 & 0.05 & 0.05 \\
$8.1-2$ & Min-Max & $6.3-7.2$ & $5.0-6.7$ & $76-97$ & $70-90$ & $0.5-0.7$ & $1.1-1.8$ & $0.1-0.4$ & $0.1-0.3$ \\
$(\mathrm{n}=6)$ & M & 6.89 & 6.1 & 83.72 & 83.33 & 0.6 & 1.5 & 0.22 & 0.18 \\
& SD & 0.33 & 0.7 & 8.82 & 8.16 & 0.09 & 0.25 & 0.12 & 0.1 \\
$12.1-16$ & Min-Max & $7.5-8.5$ & $6.4-7.4$ & $86-140$ & $80-150$ & $0.5-0.8$ & $1.1-2.2$ & $0.1-0.2$ & 0.2 \\
$(\mathrm{n}=4)$ & M & 8.05 & 6.98 & 109.23 & 90 & 0.7 & 1.55 & 0.13 & 0.18 \\
& SD & 0.42 & 0.43 & 27.15 & 14.14 & 0.14 & 0.47 & 0.05 & 0.05 \\
$16.1-20$ & Min-Max & $8.0-9.4$ & $7.2-9.7$ & $129-153$ & $150-160$ & $0.5-0.8$ & $1.5-1.7$ & $0.2-0.4$ & $0.1-0.3$ \\
$(\mathrm{n}=3)$ & M & 8.47 & 8.23 & 142.33 & 161.67 & 0.67 & 1.6 & 0.27 & 0.2 \\
& SD & 0.81 & 1.31 & 12.22 & 16.07 & 0.15 & 0.1 & 0.12 & 0.1 \\
$20.1-24$ & Min-Max & $7.8-10.0$ & $7.1-8.5$ & $116-200$ & $120-200$ & $0.5-0.9$ & $1.4-2.0$ & $0.2-0.3$ & $0.2-0.3$ \\
$(\mathrm{n}=3)$ & M & 9.03 & 7.9 & 158.33 & 158.33 & 0.7 & 1.6 & 0.23 & 0.23 \\
& SD & 1.12 & 0.72 & 42 & 40.1 & 0.2 & 0.35 & 0.06 & 0.06 \\
$28.1-32$ & Min-Max & $9.0-12.1$ & $6.8-9.8$ & $165-250$ & $180-300$ & $0.7-1.0$ & $1.1-2.2$ & $0.2-0.3$ & $0.2-0.4$ \\
$(\mathrm{n}=4)$ & M & 10.68 & 8.58 & 225.43 & 220 & 0.8 & 1.75 & 0.25 & 0.28 \\
& SD & 1.47 & 1.39 & 49.34 & 54.16 & 0.14 & 0.48 & 0.06 & 0.1 \\
\hline
\end{tabular}

CV: cardiac vertical axis, CH: cardiac horizontal axis, RV: right ventricle, LV: left ventricle, RA: right atrium, LA: left atrium

Table 2. Measurements, mean (M), and standard deviation (SD) of the variables considered for canine heart morphometry as a function of body weight

\begin{tabular}{|c|c|c|c|c|c|c|c|c|c|}
\hline $\begin{array}{l}\text { Weight } \\
\text { range } \\
(\mathrm{Kg})\end{array}$ & Variables & $\begin{array}{l}\text { Vertical } \\
\text { axis RV } \\
(\mathrm{cm})\end{array}$ & $\begin{array}{l}\text { Vertical } \\
\text { axis LV } \\
(\mathrm{cm})\end{array}$ & $\begin{array}{l}\text { Horizontal } \\
\text { axis RV } \\
(\mathrm{cm})\end{array}$ & $\begin{array}{l}\text { Horizontal } \\
\text { axis LV } \\
(\mathrm{cm})\end{array}$ & $\begin{array}{l}\text { Vertical } \\
\text { axis } \\
\text { RA } \\
\text { (cm) }\end{array}$ & $\begin{array}{l}\text { Vertical } \\
\text { axis LA } \\
(\mathrm{cm})\end{array}$ & $\begin{array}{l}\text { Horizontal } \\
\text { axis RA } \\
(\mathrm{cm})\end{array}$ & $\begin{array}{l}\text { Horizontal } \\
\text { axis LA } \\
(\mathrm{cm})\end{array}$ \\
\hline \multirow{3}{*}{$1-4(n=3)$} & Min-Max & $1.5-2.7$ & $1.5-2.7$ & $1.3-2.4$ & $0.6-1.8$ & $0.7-1.2$ & $0.7-0.8$ & $0.7-0.8$ & $1.1-1.2$ \\
\hline & $\mathrm{M}$ & 2.03 & 1.9 & 1.03 & 1 & 1 & 0.83 & 0.77 & 1.17 \\
\hline & SD & 0.61 & 0.56 & 0.67 & 0.26 & 0.1 & 0.06 & 0.06 & 0.06 \\
\hline \multirow{3}{*}{$\begin{array}{l}4.1-8 \\
(n=7)\end{array}$} & Min-Max & $2.2-2.9$ & $2.6-3.5$ & $2.6-3.5$ & $1.6-2.1$ & $1.5-2.4$ & $0.6-1.2$ & $1.0-1.7$ & $1.1-1.5$ \\
\hline & $\mathrm{M}$ & 2.59 & 3.04 & 1.8 & 2.06 & 1.34 & 0.89 & 1.24 & 1.3 \\
\hline & SD & 0.22 & 0.34 & 0.16 & 0.34 & 0.21 & 0.22 & 0.23 & 0.13 \\
\hline \multirow{3}{*}{$\begin{array}{l}8.1-12 \\
(n=6)\end{array}$} & Min-Max & $2.5-3.8$ & $2.5-3.8$ & $3.2-4.2$ & $1.3-2.7$ & $1.3-3.2$ & $1.0-1.5$ & $1.0-2.4$ & $1.1-1.7$ \\
\hline & $\mathrm{M}$ & 3.07 & 3.72 & 2.15 & 2.35 & 1.6 & 1.17 & 1.52 & 1.45 \\
\hline & SD & 0.5 & 0.37 & 0.48 & 0.61 & 0.11 & 0.25 & 0.47 & 0.2 \\
\hline \multirow{3}{*}{$\begin{array}{l}12.1-16 \\
(n=4)\end{array}$} & Min-Max & $3.4-4.7$ & $3.4-4.7$ & $3.5-4.8$ & $1.8-2.7$ & $2.0-3.3$ & $1.3-1.8$ & $1.6-3.1$ & $1.6-2.1$ \\
\hline & $\mathrm{M}$ & 3.8 & 4.18 & 2.18 & 2.6 & 1.85 & 1.53 & 1.93 & 1.83 \\
\hline & $\mathrm{SD}$ & 0.61 & 0.56 & 0.5 & 0.55 & 0.47 & 0.21 & 0.82 & 0.22 \\
\hline \multirow{3}{*}{$\begin{array}{l}16.1-20 \\
(n=3)\end{array}$} & Min-Max & $3.3-3.6$ & $3.3-3.6$ & $3.7-4.4$ & $2.1-3.3$ & $2.1-3.3$ & $1.3-1.7$ & $1.3-2.3$ & $1.5-2.0$ \\
\hline & $\mathrm{M}$ & 3.47 & 4.13 & 1.73 & 2.8 & 1.87 & 1.47 & 1.77 & 1.83 \\
\hline & SD & 0.15 & 0.38 & 0.31 & 0.62 & 0.23 & 0.21 & 0.5 & 0.29 \\
\hline \multirow{3}{*}{$\begin{array}{l}20.1-24 \\
(n=3)\end{array}$} & Min-Max & $3.1-4.3$ & $3.1-4.3$ & $4.4-4.7$ & $2.4-3.0$ & $1.8-3.6$ & $1.4-2.2$ & 2 & $1.3-1.8$ \\
\hline & $\mathrm{M}$ & 3.67 & 4.5 & 2.77 & 2.6 & 2.57 & 1.83 & 2 & 1.53 \\
\hline & SD & 0.6 & 0.17 & 0.32 & 0.92 & 0.51 & 0.4 & 0.1 & 0.25 \\
\hline \multirow{3}{*}{$\begin{array}{l}28.1-32 \\
(n=4)\end{array}$} & Min-Max & $3.4-4.3$ & $3.4-4.3$ & $4.5-5.6$ & $2.2-3.8$ & $1.8-4.0$ & $1.4-3.0$ & $1.5-2.0$ & $1.8-2.4$ \\
\hline & $\mathrm{M}$ & 4 & 5.23 & 2.93 & 2.95 & 2.33 & 1.93 & 1.88 & 2.03 \\
\hline & $\mathrm{SD}$ & 0.41 & 0.49 & 0.75 & 0.9 & 0.7 & 0.74 & 0.25 & 0.29 \\
\hline
\end{tabular}

RV: right ventricle, LV: left ventricle, RA: right atrium, LA: left atrium 
Table 3. Percentage of heart weight relative to body weight and sex of the dogs

\begin{tabular}{llllllll}
\hline Sex & BW $(\mathrm{Kg})$ & HW $(\mathrm{g})$ & $\% \mathrm{HW}$ & Sex & BW $(\mathrm{Kg})$ & HW $(\mathrm{g})$ & $\% \mathrm{HW}$ \\
\hline $\mathrm{F}$ & 2.6 & 24.5 & 0.9 & M & 11.15 & 93.0 & 0.8 \\
$\mathrm{~F}$ & 2.75 & 25.23 & 0.9 & F & 13.3 & 86.78 & 0.7 \\
M & 3.4 & 33.27 & 1.0 & F & 13.85 & 152.0 & 1.1 \\
M & 5.4 & 49.5 & 0.9 & F & 15.3 & 139.4 & 0.9 \\
F & 5.6 & 41.8 & 0.7 & M & 15.5 & 101.3 & 0.7 \\
F & 5.75 & 62.0 & 1.1 & F & 16.15 & 153.0 & 0.9 \\
F & 6.4 & 50.39 & 0.8 & M & 16.25 & 145.0 & 0.9 \\
F & 6.55 & 55.7 & 0.9 & M & 16.4 & 129.5 & 0.8 \\
M & 6.6 & 47.34 & 0.7 & F & 21.0 & 116.0 & 0.6 \\
F & 6.75 & 63.72 & 0.9 & M & 21.4 & 159.0 & 0.7 \\
M & 8.1 & 76.14 & 0.9 & M & 23.4 & 200.0 & 0.9 \\
M & 9.0 & 81.68 & 0.9 & F & 28.15 & 168.8 & 0.6 \\
M & 9.0 & 96.5 & 1.1 & F & 28.25 & 207.3 & 0.7 \\
F & 9.05 & 77.14 & 0.9 & M & 29.7 & 278.6 & 0.9 \\
F & 9.1 & 78.0 & 0.9 & M & 30.15 & 250.0 & 0.8 \\
\hline
\end{tabular}

BW: Body weight; HW: heart weight; $\% \mathrm{HW}$ : percent of heart weight.

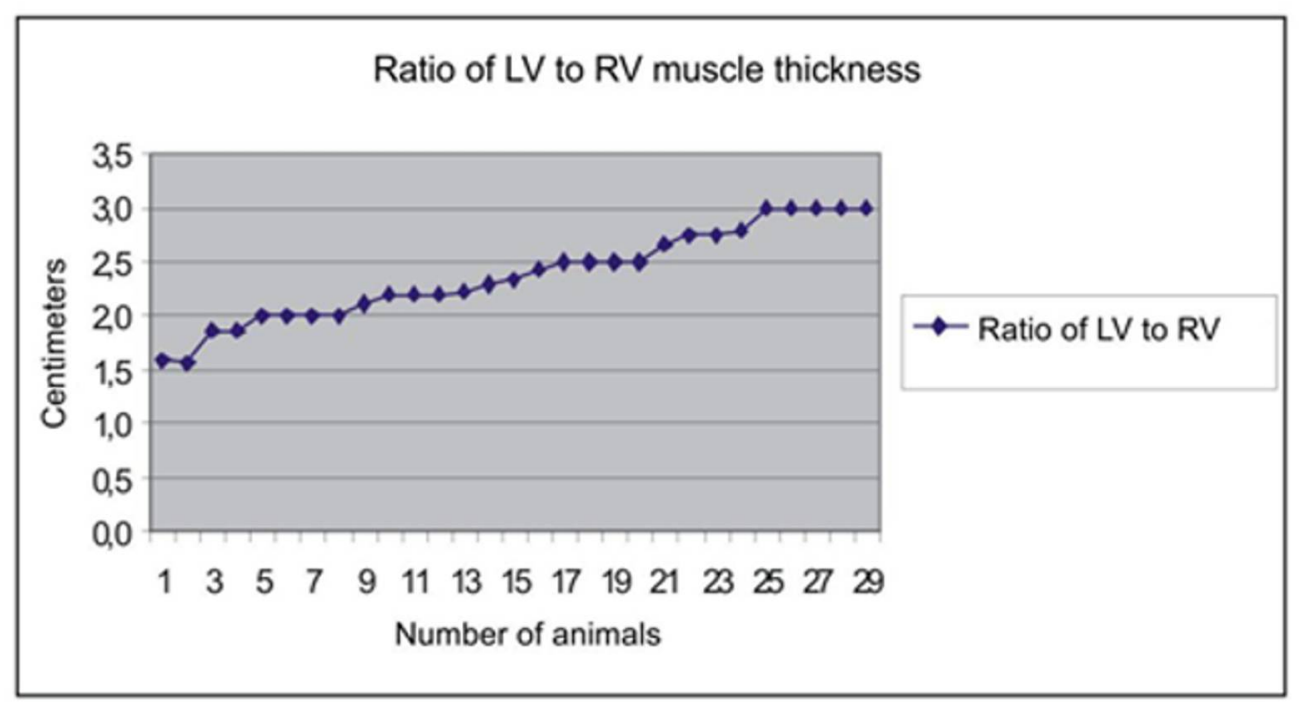

Figure 3. Ratio of left ventricular to right ventricular muscle thickness.

\section{Discussion}

During animal necropsy, the presence or severity of heart disease is usually evaluated subjectively ${ }^{(12)}$, and hypertrophy may go unnoticed if discreet or else not indicate its degree of severity ${ }^{(5)}$. To reduce this subjectivity, this study provides objective information about the morphometry of the canine heart, indicating that the normal heart represents a percentage of body weight. It also provides data on the proportion of muscle thickness of the ventricles and the relative ratio between the vertical and horizontal axes, which is useful for assessing the main changes in cardiac volume, hypertrophy and, dilation. 
To avoid subjectivity, the weight of the human heart can be compared to pre-established reference values $^{(12)}$; however, when it comes to animals, such values are still scanty. In this context, therefore, the present study intends to contribute to the formation of a reference database for the macroscopic evaluation of cardiac normality in mongrel dogs. Leifsson ${ }^{(13)}$ stated that each institution or diagnostic center should establish normal values for healthy dogs from the local population, since they concluded that values considered normal may vary in a complex manner from one region to another.

We found no reference values for cardiac measurements under macroscopic examination, so we compared our data with those reported by Boon ${ }^{(14)}$, who described the expected thickness of the left atrium in the systole and diastole cardiac cycle during echocardiographic examination. However, all the numbers provided by the author are lower than those found in this study. This may be attributed to the possible change in ventricular wall thickness when rigor mortis sets $\mathrm{in}^{(6)}$, or simply to differences in processing procedures. For example, Boon ${ }^{(14)}$ considered live animals in the systole and diastole cardiac cycle and the occurrence of minor variations between measurements taken from images and those obtained under macroscopic examination is common. In contrast, Crippa et al. ${ }^{(15)}$ used echocardiography to measure the left ventricular wall thickness of Beagles weighing between 8 and $11 \mathrm{~kg}$, and reported values close to those found in this study for dogs with similar body weight.

In this study, the heart to body weight ratio of the dogs ranged from 0.6 to $1.1 \%$; this results are similar to those described by other authors: 0.61 to $0.94 \%{ }^{(5)} ; 0.66$ to $1.20 \%{ }^{(4)}$, and 0.66 to $1.20 \%{ }^{(7)}$. It should be noted that Ghoshal ${ }^{(3)}$ mentions a slightly higher percentage range, reporting a heart to bodyweight ratio of 0.5 to $2.2 \%$.

Schoning et al. ${ }^{(16)}$, Bienvenu \& Drolet ${ }^{(5)}$, Werner et al. ${ }^{(6)}$, and Carvalho et al. ${ }^{(4)}$ stated that the heart weight to body weight ratio is not influenced by the patient's sex. This study found no differences in the cardiac measurements of male and female dogs. In other words, the cardiac morphometry is related with the animal' weight and not its sex.

It is noteworthy that we found no studies about the ratio between the vertical and the horizontal cardiac axes of dogs, which is a useful measure for assessing normal heart size, regardless of the animal's body weight.

With regard to the ratio of ventricular wall thickness, Robinson \& Robinson ${ }^{(7)}$ reported that the muscle of the left ventricle is approximately two to fourfold thicker than that of the right ventricle, while Van Vleet et al. ${ }^{(2)}$ found that it is about threefold thicker. This is similar to the ratio of 1.6 to three, with an average of 2.4-fold, which was observed in this study. In addition, Werner et al. ${ }^{(6)}$ measured the relative wall thickness ratio of the right and left ventricles and found an average of 0.445 . In the present study, this ratio was found to be 0.43 .

It is important to note that the animals were evaluated in terms of body weight and not of size (small, medium, large, and giant), given the difficulties in standardizing this measure. Goldston \& Hoskins ${ }^{(17)}$ and Bentubo et al. ${ }^{(18)}$ are examples of this kind of study. The authors rated dogs according to size, but took into account only the animal's body weight, disregarding aspects such as cachexia and obesity, which renders the evaluation inconsistent. Moreover, there are no reports about classifying dogs according to size associating more than one measure, such as height and weight, for example. 


\section{Conclusions}

A table listing reference values for the different cardiac measures is useful for the macroscopic evaluation of normality of the canine heart during necropsy examination. The relation between heart weight and body weight, regardless of the animal's sex, is a suitable parameter for establishing ratios with a view to evaluating the presence and severity of increased muscle mass in dogs (hypertrophy). Regardless of body weight, the ratio between vertical and horizontal cardiac axes is a useful tool for assessing the normality of canine heart size. The proportion of muscle thickness of the left and right ventricles is a suitable tool for confirming the macroscopic diagnosis of hypertrophy or ventricular dilation.

\section{Acknowledgments}

The authors gratefully acknowledge the School of Veterinary Medicine and Animal Science of the Federal University of Goias (EVZ-UFG) for their support of this work.

\section{References}

1. Junqueira LC, Carneiro J: Sistema circulatorio. In Histologia Básica - texto e atlas. 12th edition. Rio de Janeiro: Guanabara Koogan. 2013;199-216.

2. Miller LM, Van Vleet JF, Gal A: Cardiovascular system. In Pathologic Basis of Veterinary Disease. 5th edition. Edited by McGavin MD, Zachary JF. Missouri: Elsevier. 2013;539-588.

3. Ghoshal NG: Coração e artérias do carnívoro. In Anatomia dos Animais Domésticos. 5th edition. Edited by Getty R, Sisson S, Grossman JD. Rio de Janeiro: Guanabara Koogan. 1986;1497-1549.

4. Carvalho LMM, Andrade FHE, Alves FR, Guerra PC, Sousa AL: Morfometria cardíaca externa em cães adultos. Pesquisa em Foco. 2002;10:1-2.

5. Bienvenu JG, Drolet R: A quantitative study of cardiac ventricular mass in dogs. Can J Vet Res. 1991;55:305-309.

6. Werner PR, Bolson J, Battisti MKB: Morfometria cardíaca para o diagnóstico de cardiopatias em cães. Arq Ciências Veterinárias e Zool da UNIPAR. 2001;4:181-188.

7. Robinson WF, Robinson NA: Cardiovascular System. In Jubb, Kennedy \& Palmer's Pathology of Domestic Animals - volume 3. 6th edition. Edited by Maxie MG. London: Elsevier Saunders. 2015;1-101.

8. Teixeira VPA, Pereira SAL, Rodrigues DBR, Lino Junior RS, Oliveira FA, Castro ECC, Reis MA: Princípios Básicos e Aplicações da Morfometria. Uberaba; 2005.

9. Cunningham SM, Rush JE, Freeman LM, Brown DJ, Smith CE: Echocardiographic ratio indices in overtly healthy boxer dogs screened for heart disease. J Vet Intern Med. 2008; 22:924-930.

10. Smets P, Daminet S, Wess G: Simpson's method of discs for measurement of echocardiographic enddiastolic and end-systolic left ventricular volumes: breed-specific reference ranges in boxer dogs. J Vet Intern Med. 2014;28:116-122.

11. Wess G, Mäurer J, Simak J, Hartmann K: Use of Simpson's method of disc to detect early echocardiographic changes in doberman pinschers with dilated cardiomyopathy. J Vet Intern Med. 2010; 24:1069-1076. 
12. Davies MJ, Pomerance A, Lamb D: Techniques in examination and anatomy of the heart. In The pathology of the heart. Edited by Pomerance A, Davies MJ. London: Blackwell Scientific Publications. 1975;1-45.

13. Leifsson PS: Extended macroscopic examination of the heart. In Necropsy: A Handbook and Atlas. Edited by Jensen HE. Frederiksberg: Biofolia. 2011;179-186.

14. Boon JA: Veterinary Echocardiography. 2nd edition. Baltimore: John Wiley \& Sons; 2011.

15. Crippa L, Ferro E, Melloni E, Brambilla P, Cavalletti E: Echocardiographic parameters and indices in the normal Beagle dog. Lab Anim. 1992;26:190-195.

16. Schoning P, Erickson H, Milliken GA: Body weight, heart weight, and heart-to-body weight ratio in greyhounds. Am J Vet Res. 1995;56:420-422.

17. Goldston RT, Hoskins JD: Geriatria e Gerontologia do Cão e Gato. 2nd edition. São Paulo: Roca; 2008.

18. Bentubo HDL, Tomaz MA, Bondan EF, Lallo MA: Expectativa de vida e causas de morte em cães na área metropolitana de São Paulo (Brasil). Ciênc Rural. 2007; 37:1021-1026. 